\title{
バイオディーゼル混合燃料の熱分解と微粒子低減に関する基礎研究*
}

\author{
野毛 宏文 ${ }^{* 1}$, 細見 尚希 ${ }^{* 2}$, 木戸口善行 ${ }^{* 3}$
}

\section{A Fundamental Study of Role of Thermal Decomposition of Diesel Fuel Mixed with Bio-Diesel Fuel on PM Reduction}

\author{
Hirofumi NOGE ${ }^{* 1}$, Naoki HOSOMI and Yoshiyuki KIDOGUCHI \\ ${ }^{* 1}$ Maizuru National College of Technology. Dept. of Mechanical Engineering \\ Azashiroya 234, Maizuru, Kyoto, 625-8511 Japan
}

The purpose of this study is to investigate the cause of PM reduction by diesel fuel (Solvent: $\mathrm{C}_{12}, \mathrm{C}_{13}, \mathrm{C}_{14}$ ) mixed with bio-diesel fuel (Methyl Decanoate: $\mathrm{C}_{9} \mathrm{H}_{19} \mathrm{COOCH}_{3}$ ) with focusing on the thermal decomposition in diesel combustion atmosphere. To make a heavy duty diesel combustion atmosphere, a flow reactor and a co-flow diffusion burner were used. The thermally decomposed fuel produced in the flow reactor was introduced into the co-flow diffusion burner directly. To study the relation between thermal decomposition and PM reduction, the chemical substances produced in the reactor and PM produced by the combustion of the burner were quantitatively and qualitatively analyzed by some analytical devices. The emission measurement with diffusion burner shows that the bio-diesel blended fuel exhausts PM in concentration 20 30\% less than diesel fuel. The analysis indicates that, due to oxygen-containing fuel, the bio-diesel fuel can oxidize thermally decomposed components of $\mathrm{C}_{2} \mathrm{H}_{2}$ and PAHs that may become pre-cursers of PM.

Key Words : Diesel Engine, Fuel, Combustion, Combustion Products, Pyrolysis, Particultae Matter, PAHs, Soot

\section{1. はじめに}

地球温暖化防止およびエネルギー有効利用のためバイオ燃料の需要が高まっており, ディーゼルエンジンにお いては，植物油や廃食用油のエステル交換反応で生成されたバイオディーゼル燃料（BDF）が使用されている.

BDF は燃料分子中に酸素を含んでおり, BDF を使用した場合のディーゼル排気においては, 微粒子状物質 (PM) の低減に効果的であることが知られている。しかし，BDFによる PM 低減反応機構はあまり知られていない. ま た，BDF の燃焼における反応機構を報告した研究(1)も少なく，ディーゼルエンジンにおいては，モータリング時 の酸化反応機構の一部が報告(2)されている程度である。一方, 菜種油, 楖子油, 大豆油, 廃食用油由来の BDF が ディーゼルエンジンの排気, 機関性能に及ぼす影響については盛んに研究され(例えば3-5), BDF の燃料性状と PM 低 減の関係は明らかにされつつあるが, 依然としてディーゼル燃焼過程で BDF が PM 低減を引き起こす主な化学反 応経路は不明である.

一方，DME あるいはエタノールなどの含酸素燃料による燃焼反応機構は Curran ${ }^{(6)}$ や Marinov ${ }^{(7)}$ によって提案さ れており，これらをディーゼル燃焼雰囲気に適用し、化学反応論解析を行うことで、PM 生成あるいは低減に関 する主要な化学反応を予測することが可能になりつつある ${ }^{(8),(9)}$. しかしながら, BDF のように高分子の直鎖飽和 炭化水素を含む燃料においては，燃焼反応機構が十分明らかにされておらず，このため理論的な化学反応解析は 難しく, 実験により主要な PM 低減反応を見出寸必要がある．また，ディーゼル燃焼過程においては，とくに拡

\footnotetext{
${ }^{*}$ 原稿受付 2010 年 10 月 30 日

*1 正員, 舞鶴工業高等専門学校 機械工学科（下625-8511 京都府舞鶴市字白屋 234 番地）

*2 舞鶴工業高等専門学校 建設生産システム専攻 (現 旭化成 (株) )

*3 正員, 徳島大学大学院 ソシオテクノサイエンス研究部

E-mail: noge@maizuru-ct.ac.jp
} 
散燃焼が主となる高負荷領域で NOx と PM の同時低減が難しいことから, 拡散燃焼場で BDF の分子構造が PM 低減を引き起こす反応を調べることが重要と考える.

ディーゼル燃焼における拡散燃焼場では，燃料過濃な領域が存在する。燃料過濃領域では酸素が少なく，系の 反応としては熱分解反応が進行しや寸いと考えられる. また，PM は然料過濃な燃焼場で生成されやすいことか ら, 熱分解反応が PM の生成と低減に関係すると考えられる.

本研究では, BDF 混合燃料の熱分解反応と PM 低減の関係を調べるため, 流通反応装置と層流拡散バーナを用 いた実験を行った. 流通反応装置では BDF 混合燃料の熱分解を行い, 流通反応装置で熱分解した燃料を直ちに層 流拡散バーナで燃焼させることにより PM を生成する.これらの装置では, 実機関同様に, BDF 混合燃料が蒸発, 混合, 熱分解, 拡散燃焼, 排気物質生成一至る過程を模擬しており, この過程において, BDF 燃料の熱分解と PM 生成, 低減の関係を調べた.

\section{2. 実験装置および実験方法}

図 1 に実験装置の概略を示す. 本装置は既報 ${ }^{(10)}$ と同様に流通反応装置と層流拡散バーナで構成される.まず, 噴射弁より噴射させた燃料を蒸発部で気化させてキャリアガスの窒素 $\left(\mathrm{N}_{2}\right)$ と燃料・窒素流量比 $\mathrm{F} / \mathrm{G}=0.07,0.10$, 0.13 で混合する. この混合気を赤外線中央集光炉 (真空理工 E410) に置かれたムライト製反応管 $\left(3 \mathrm{Al}_{2} \mathrm{O}_{3} \cdot 2 \mathrm{SiO}_{2}\right.$, 内径 $9 \mathrm{~mm}$ ，加熱有効長 $265 \mathrm{~mm} ）$ に導入して高温に曝すことにより，大気圧下でディーゼル燃焼の熱分解過程を 模擬する. 次いで, この熱分解成分を含む混合気を $300^{\circ} \mathrm{C}$ 保持された保温管に通して下流の層流拡散バーナに 導き，熱分解成分の燃焼を模擬する．このとき，燃料を十分に熱分解させて層流拡散バーナに供給するため，炉 内で混合気の滞留時間を $\mathrm{tr}=40 \mathrm{~ms}$ ，反応管内温度を $\mathrm{Tr}=1350 \mathrm{~K}$ おび $1500 \mathrm{~K}$ とた。

層流拡散バーナはステンレス製同軸円管で構成され，内管（内径 $22.65 \mathrm{~mm}$ ，外径 $24.45 \mathrm{~mm}$ ）には流通反応装 置で生成した然料・キャリアガス混合気，外管（内径 $38 \mathrm{~mm}$ ，外径 $40 \mathrm{~mm}$ ）には酸化剤として酸素と窒素を供給 した. 酸化剂の流速は, 燃料・キャリアガス流速（V) と同一とし, 層流拡散バーナにおける燃焼では, 総括当 量比 $\left(\phi_{\mathrm{b}}\right)=1.0,1.5,2.0$ とした．また，バーナは，周囲空気の流入を防ぐため，石英円管（内径 $123.4 \mathrm{~mm}$, 外 径 $130.3 \mathrm{~mm}$, 高さ $130 \mathrm{~mm})$ で囲った.

なお，熱分解成分の分析のため，熱分解ガスの一部を高温サンプラ（Yanaco GHS-50）により FID 型検出器付 ガスクロマトグラフ GC（Yanaco G3800, カラムは内径 3mm, 長さ $3 \mathrm{~m}$ の Squalane カラム) 几導入し, 低沸点炭 化水素（LHCs）の定性と定量を行った.

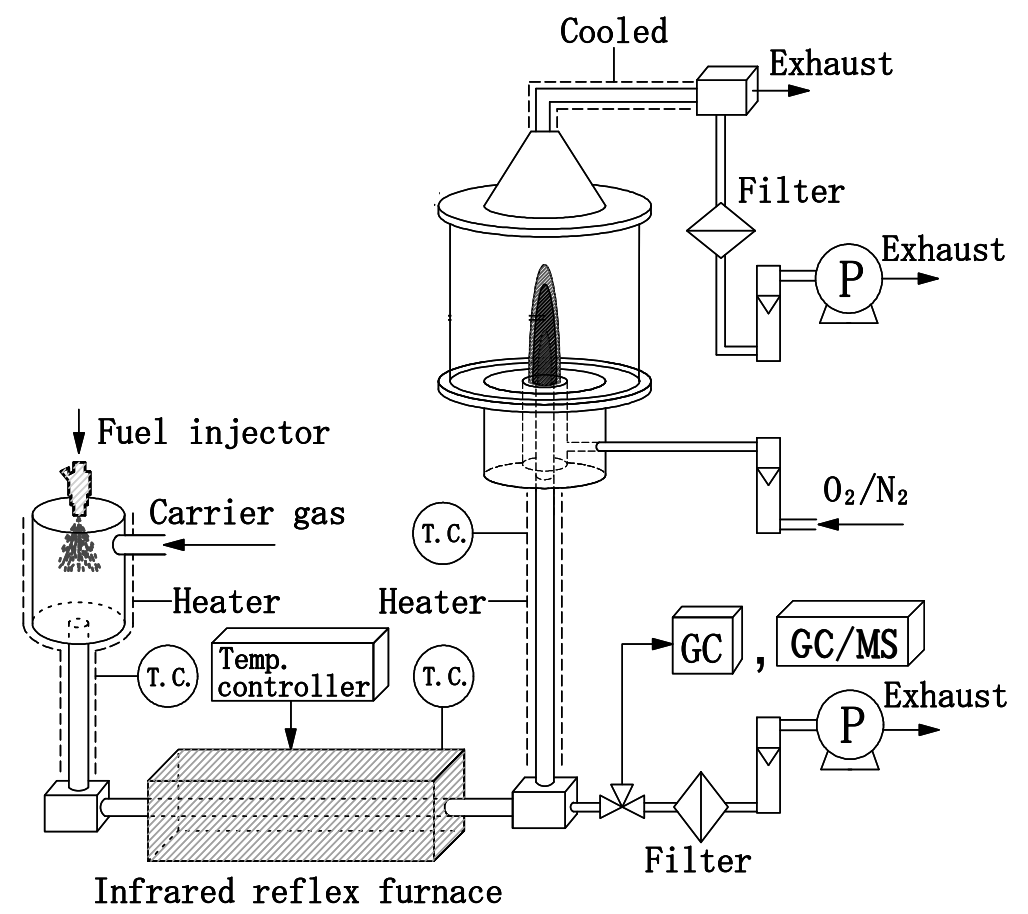

Fig.1 Schematic diagram of experimental setup 
また，多環芳香族炭化水素 (PAHs) を同定するために，ガス成分をテフロンフィルタ（MILLIPORE FHLP04700） で採集し, Soxhlet 抽出法によりジクロロメタン（Dichloromethane 5000）中に試料を溶出させ， $\mathrm{N}_{2}$ パージにより 10 倍に濃縮した。この試料をガスクロマトグラフ質量分析計 GC/MS（Shimadzu GCMS-QP2010 Plus）に $1 \mu l$ 注入 し，NIST ライブラリを用いて定性を行った。このとき分離カラムには Capillary カラム RTX-5MS（Resteck International）を使用した.

さらに, 熱分解で生成した微小 PM 粒子はテフロンフィルタで捕集し, 乾燥させた後, Soxhletにより固形炭素 分（す寸，Solid）を抽出した，そして，超音波照射によりテフロンフィルタから離脱した Solid のうち直径 $20 \mathrm{~nm}$ 以下のものをシリンジフィルタ（孔径 20nm, Anotop10,Wattman）で選別し、7ml の NMP（N-メチル-ピロリドン） 中に均一分散させ，可視・紫外吸光光度計（UVmini-1240 島津）により吸光測定を行い，すすによる吸光度を調 ベた.

一方，燃焼後の排出ガスに含まれるPMについては，その生成量と可溶有機成分（SOF）に含まれる多環芳香 族成分（PAHs）を調べた．PM 生成量は，排出ガスの一部を 4 l/min で等速吸引して PM をテフロンフィルタに捕 集し，その後，恒温室で約 12 時間乾燥させ，捕集前後のフィルタ重量を天秤（研精工業 HR-202i）で計測する ことにより求めた．さらに，PM は Soxhlet 抽出法により SOF と Solid に分離した．SOF に含まれる PAHs は，分 光蛍光光度計 FL（日立 F-7000）を用いて, 蛍光波長により調べた.

供試燃料には，軽油の主成分を構成している直鎖飽和炭化水素燃料として Solvent $\left(\mathrm{C}_{12} \mathrm{H}_{26}: 27 \mathrm{wt} . \%, \mathrm{C}_{13} \mathrm{H}_{28}\right.$ : $47 \mathrm{wt} . \%, \mathrm{C}_{14} \mathrm{H}_{30}$ : 26wt.\%) を標準燃料に用い, Solventに BDF を模擬したデカン酸メチル $\left(\mathrm{C}_{9} \mathrm{H}_{19} \mathrm{COOCH}_{3}\right)$ を $10 \mathrm{vol} . \%$ 混合した燃料（MD10）を用いた，BDF には，エステル基を含む複数の FAME（脂肪酸メチルエステル）が含ま れており，FAMEの混合割合は，燃料毎に異なるが，本研究ではBDF の代表燃料として Solvent と概ね炭素数が 同じデカン酸メチルを適用した. また比較燃料として, Solventに含酸素燃料のエタノール $\left(\mathrm{C}_{2} \mathrm{H}_{5} \mathrm{OH}\right)$ を $10 \mathrm{vol} . \%$ 混合した燃料（E10）とエタノール 100vol.\%燃料（E100）を用いた.

\section{3. 実 験 結 果}

\section{$3 \cdot 1 \quad P M$ 低減と熱分解における低沸点熱分解炭化水素の生成挙動}

はじめに，図 2 に Solvent，MD10，E10 熱分解温度 $\operatorname{Tr}$ で熱分解させ，この熱分解成分を層流拡散バーナで総 括当量比的を変更して燃焼させて PM を測定した結果を示す.

熱分解温度，総括当量比に関わらず，MD10 と E10 は Solventより 20～30\%の PM を低減することができる. とくに，MD10 と E10 は Solventに対して過濃条件で，固形炭素成分（Solid）の低減に効果が大きい，ただし， $\mathrm{Tr}=1350 \mathrm{~K}, \phi_{\mathrm{b}}=2.0$ の条件では, MD10 は Solventより PM は減少しているものの, SOFが多い. エステル基を含 んだ然料は, 低温酸化反応場で脱炭酸反応により $\mathrm{CO}_{2}$ を生成しやすい(2)ことから, MD10の熱分解成分が層流拡 散バーナに導入されたときに $\mathrm{CO}_{2}$ が形成され，これにより燃焼温度が低下し，SOF の増加につながったと考えら れる.

つぎに, PM 低減と熱分解の関係を調べるため, 熱分解で生成する低沸点炭化水素（LHC）の定性, 定量分析 を行った結果を図 3 に示寸. 3 燃料に共通して $\mathrm{CH}_{4}, \mathrm{C}_{2} \mathrm{H}_{6}, \mathrm{C}_{2} \mathrm{H}_{4}, \mathrm{C}_{3} \mathrm{H}_{8}, \mathrm{C}_{3} \mathrm{H}_{6}, \mathrm{C}_{2} \mathrm{H}_{2}$ の生成が見られ，MD10 で は $\mathrm{n}-\mathrm{C}_{4} \mathrm{H}_{10}$ の生成も確認される. $\mathrm{Tr}=1350 \mathrm{~K}$ のとき, $\mathrm{LHC}$ 全体の生成量は Solvent $>\mathrm{E} 10 \doteqdot \mathrm{MD} 10$ となり, LHC 成分 の生成順位は 3 燃料でいずれも, $\mathrm{C}_{2} \mathrm{H}_{4}>\mathrm{CH}_{4}>$ その他化学種となり同一の傾向を示す. ただし, $\mathrm{F} / \mathrm{G}$ が 0.10 から 0.13 一と燃料割合が増加する時, Solventに比べ $\mathrm{E} 10$ と $\mathrm{MD} 10$ の $\mathrm{C}_{2} \mathrm{H}_{4}$ 増加率は小さい. 直鎖飽和炭化水素の熱分 解反応は $\beta$ ルールに依存することから ${ }^{(11)}$, Solvent では $\mathrm{C}_{2} \mathrm{H}_{4}$ の生成が盛んになり， $\mathrm{C}_{2} \mathrm{H}_{4}$ 経由による LHC あるいは その他の化学種が生成されやすいと考えられる，一方，MD10 やE10では，後述するように，無酸素状態の熱分 解䨌囲気で, $\mathrm{CO}$ あるいは $\mathrm{CO}_{2}$ の生成が確認されることから, 燃料分子中に含まれる酸素原子が炭素原子を消費 することが予測され，これが LHC の酸化ひいては、す寸前駆物質の低減を引き起こすと考えられる。

$\mathrm{Tr}=1500 \mathrm{~K}$ においても， $\mathrm{Tr}=1350 \mathrm{~K}$ と同じ種類の LHC が生成されるが, 熱分解がさらに進行し, $\mathrm{Tr}=1350 \mathrm{~K}$ に比べ ると, $\mathrm{CH}_{4}$ が増加している. また Solvent と E10においては, $\mathrm{C}_{2} \mathrm{H}_{2}$ も増加している. しかし, MD10においては, $\mathrm{C}_{2} \mathrm{H}_{2}$ が減少している. $\mathrm{C}_{2} \mathrm{H}_{2}$ の生成量を燃料間で比較した場合, いずれの当量比においても, Solvent $>$ E10 $>$ MD10 の順となっており, MD10 での生成量はとくに少ない. 燃料中の酸素質量割合は, Solvent が 0, MD10 が 2.0wt.\%, 
E10 が 3.6wt.\%であるのに対し，例えば $\mathrm{Tr}=1500 \mathrm{~K} ， \phi_{\mathrm{b}}=2.0$ の条件で，図 2 の Solvent に対する PM 低減割合を求 めるとMD10，E10でそれぞれ 24wt.\%，27wt.\%で，図 3 の LHC 低減割合はそれぞれ 14wt.\%，10wt.\%であること から, 熱分解反応において燃料中の酸素が不飽和炭化水素および LHC 全体の減少に関係し，これが PM 低減の要 因の一つになっていることが示唆される. 酸素含有率が高くなると LHC 低減率は高くなるが, MD10 では酸素含 有によるLHC，PMの低減度が高いといえる.

図 4 に純エタノール（E100）を用いて，燃焼による PM 生成と熱分解成分の LHC を調べた結果を示す.エタ ノールは，ディーゼル燃料よりも分子量が小さく，酸素原子を含んでいることからも，ほとんど PM は生成され ない. さらに, E100の熱分解成分に着目すると, 最も生成量の多い化学種は $\mathrm{CH}_{4}$ であり, 熱分解反応系でありな がら安定な化学種が生成していることがわかる.

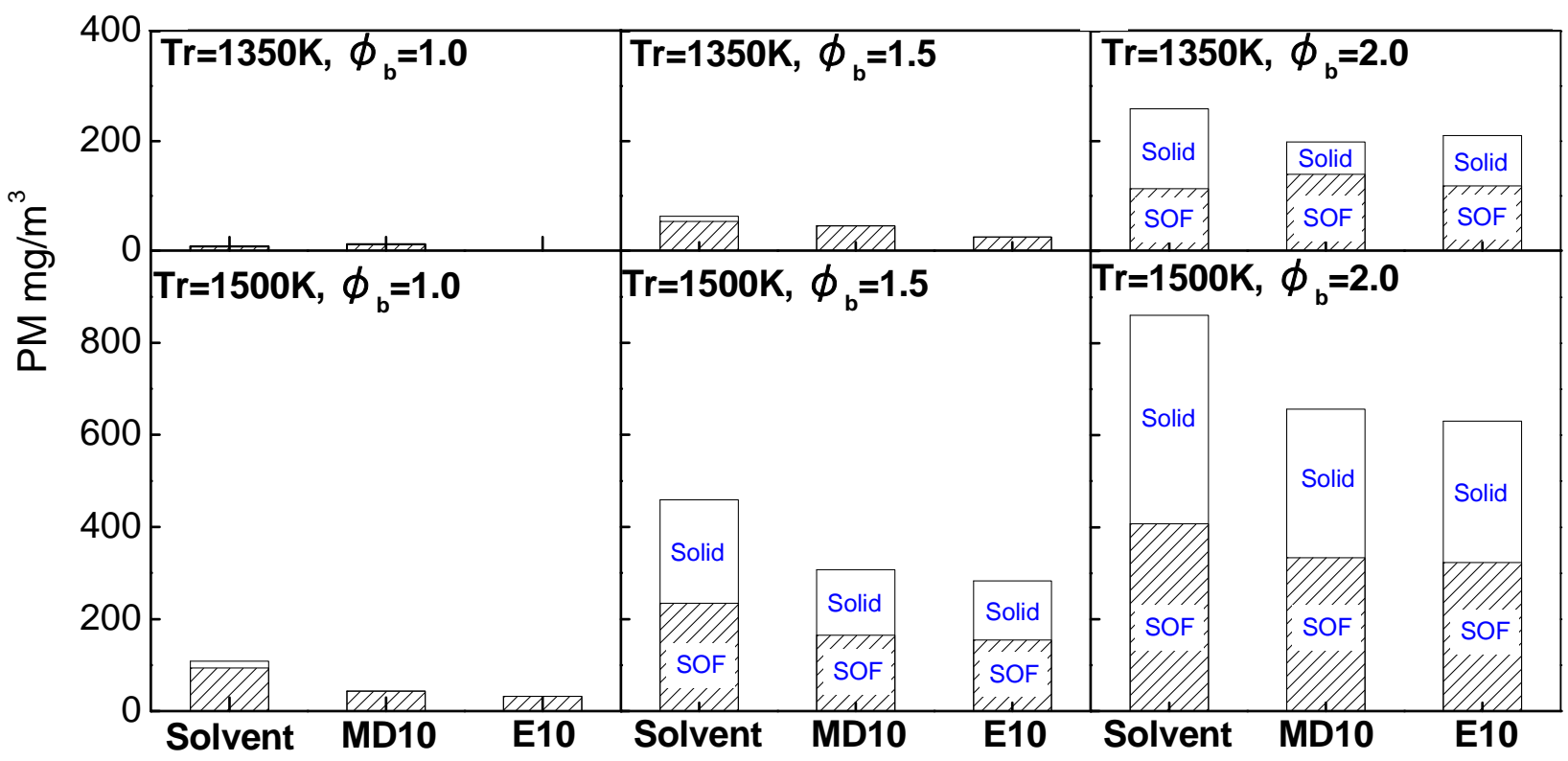

Fig.2 Comparison of exhaust PM produced by diffusion combustion fueled by thermally decomposed fuels

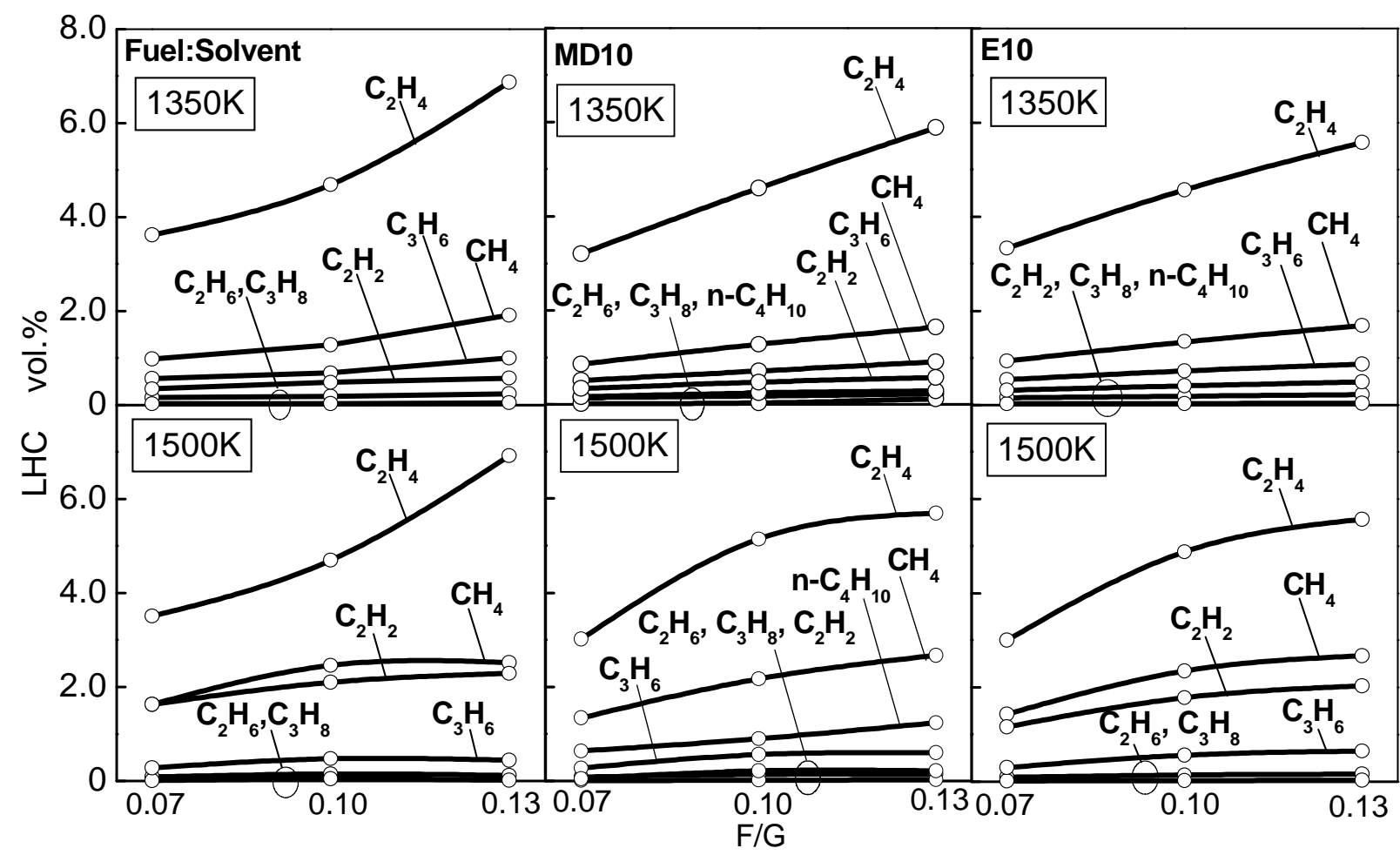

Fig. 3 LHCs production by thermal decomposition at $1350 \mathrm{~K}$ and $1500 \mathrm{~K}$ 


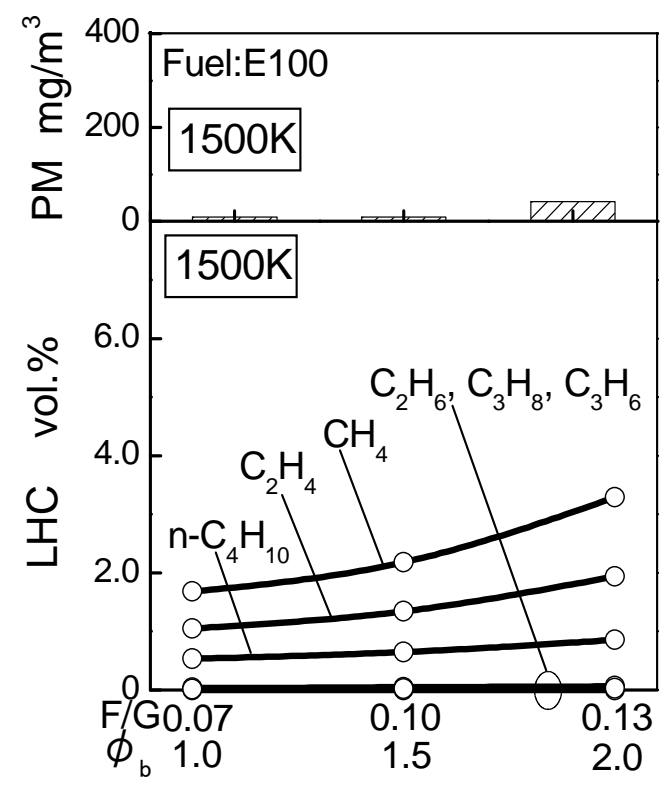

Fig.4 Thermally decomposed LHCs and exhaust PM production by pure ethanol

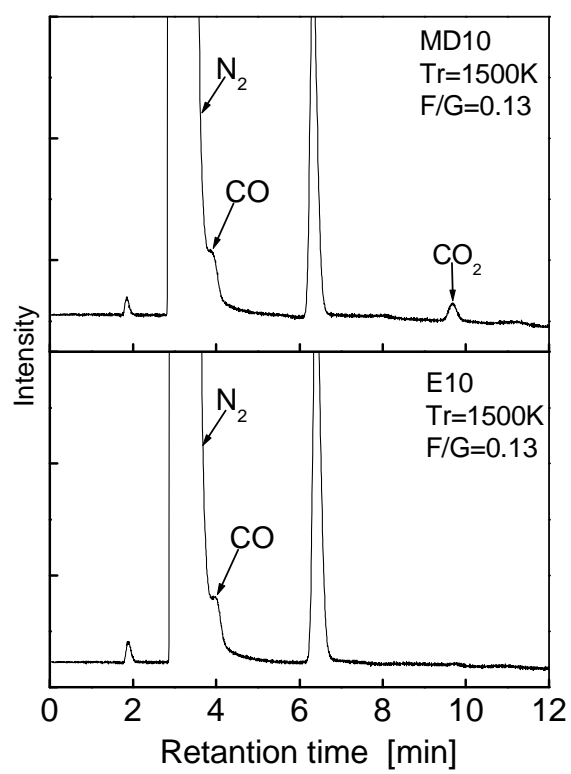

Fig.5 $\mathrm{CO}$ and $\mathrm{CO}_{2}$ production corresponding to $\mathrm{E} 10$ and MD10 thermal decomposition

また, $\mathrm{C}_{2} \mathrm{H}_{4}$ の生成は抑制され， $\mathrm{C}_{2} \mathrm{H}_{2}$ のような不飽和炭化水素は全く生成されない. 図 3,4 の結果から, 熱分解 反応において不飽和炭化水素および LHC 全体の減少が，PM 低減に関係していることが示唆される.

図 5 に，MD10，E10 の熱分解における $\mathrm{CO} ＼textrm{C O}_{2}$ の生成の様子を示寸. $\mathrm{MD} 10, \mathrm{E} 10$ どちらからも $\mathrm{CO}$ あるいは $\mathrm{CO}_{2}$ の生成が確認されることから，無酸素の熱分解において LHC が酸化されたことが分かる. とくに, MD10で は $\mathrm{CO}$ に加え $\mathrm{CO}_{2}$ の生成がみられることから，MD10 では， $\mathrm{C}_{2} \mathrm{H}_{2}$ が酸化して生成割合が小さくなっていると考え られる. MD10 では E10に比べて酸素割合が低いのにPM，LHC が比較的低減しているのは， $\mathrm{C}_{2} \mathrm{H}_{2}$ が酸化しや寸 いことにより，す寸前駆物質やPM の低減が促進されるためと考えられる.

\section{$3 \cdot 2$ PM 低減と熱分解，燃焼場におけるすす前駆物質の生成挙動}

次に，熱分解で生成する PAHs について調べた. 図 6 は GC/MS により熱分解中に生成する PAHs を分析した結 果である. 3 燃料とも 2 環から 4 環の PAHs が確認できるが，定性で明らかになったものは図中に示す 9 種類で ある.MD10，E10の PAHs の検出強度は Solvent に比べると全体的に低い. MD10 では 2-methylnaphthalene の検 出強度が比較的高いが，E10，MD10 ともに Fluorene をはじめとする 3 環以上の分子量の大きな PAHs は Solvent に比べ概ね減少している，同じ PAHs について比較したクロマトグラフでは，検出強度と生成量に相関があるた め，MD10，E10においては 3 環以上の PAHs の生成量が Solvent より少ないといえる.

図 7 は熱分解で生成した 4 環以上の PAHs の蛍光強度を測定した結果を示す. 3 燃料での蛍光波長, 蛍光強度 はいずれも概ね同じであった．372，392nm はpyrene の波長を示し，464nm は不明であるが，そのピークは長波 長側にあることから， pyreneよりも分子量の大きいPAHs と考えられる．なお，本測定方法では複数のPAHs の 蛍光を同時に計測しているため，蛍光強度の強いPAHs に他の PAHs の蛍光がマスクされた可能性はある.

次に，熱分解によって生成した直径 $20 \mathrm{~nm}$ 以下の寸寸粒子について調べた.

図 8 は Solvent と MD10 の熱分解から生成するす寸粒子の吸光度を調べた結果を示す. 得られたす寸粒子の波 形は, A.Ciajolo らが n-ヘプタンやブタンの火炎内ら採集したす寸粒子の波形(12),(13) と類似している. Solventにお いて，燃料キャリアガス質量流量比（F/G）が大きくなると，す寸粒子による吸光度は増加する．試料が溶液の 場合, 吸収の強さは溶液の濃度に比例するので, 液体試料に含まれるす寸粒子も増加したと考えられる. 一方, Solvent と MD10 で $\mathrm{Tr}=1500 \mathrm{~K}, \mathrm{~F} / \mathrm{G}=0.13$ の同一実験条件の場合, それぞれの吸光度は同じであり, 本方法での, 熱分解雰囲気における Solvent と MD10 からの寸寸粒子濃度はほぼ同じといえる. 
最後に，層流拡散燃焼を経て生成したPM中のSOFに含まれる4環以上のPAHsを蛍光分光測定した結果を図9に 示す. 測定試料は流通反応装置での熱分解温度が $\mathrm{Tr}=1500 \mathrm{~K}$ で, バーナ部での総括当量比が $\phi_{\mathrm{b}}=2.0$ である. SOF中 のPAHsの蛍光強度はSolvent $>$ E10 $>$ MD10となり, 図2に示した燃料に対するSOFあるいはPM濃度と同様の傾向に なっている.

以上より，本実験方法では熱分解における4環以上のPAHsの蛍光強度とす寸粒子濃度に関して，燃料による大 きな差異は見られないものの, 熱分解で準備されるLHCやPAHsの生成濃度が低くなると, その後の燃焼により生 成するす寸前駆物質ならびにPM濃度も低くなると考えられる.

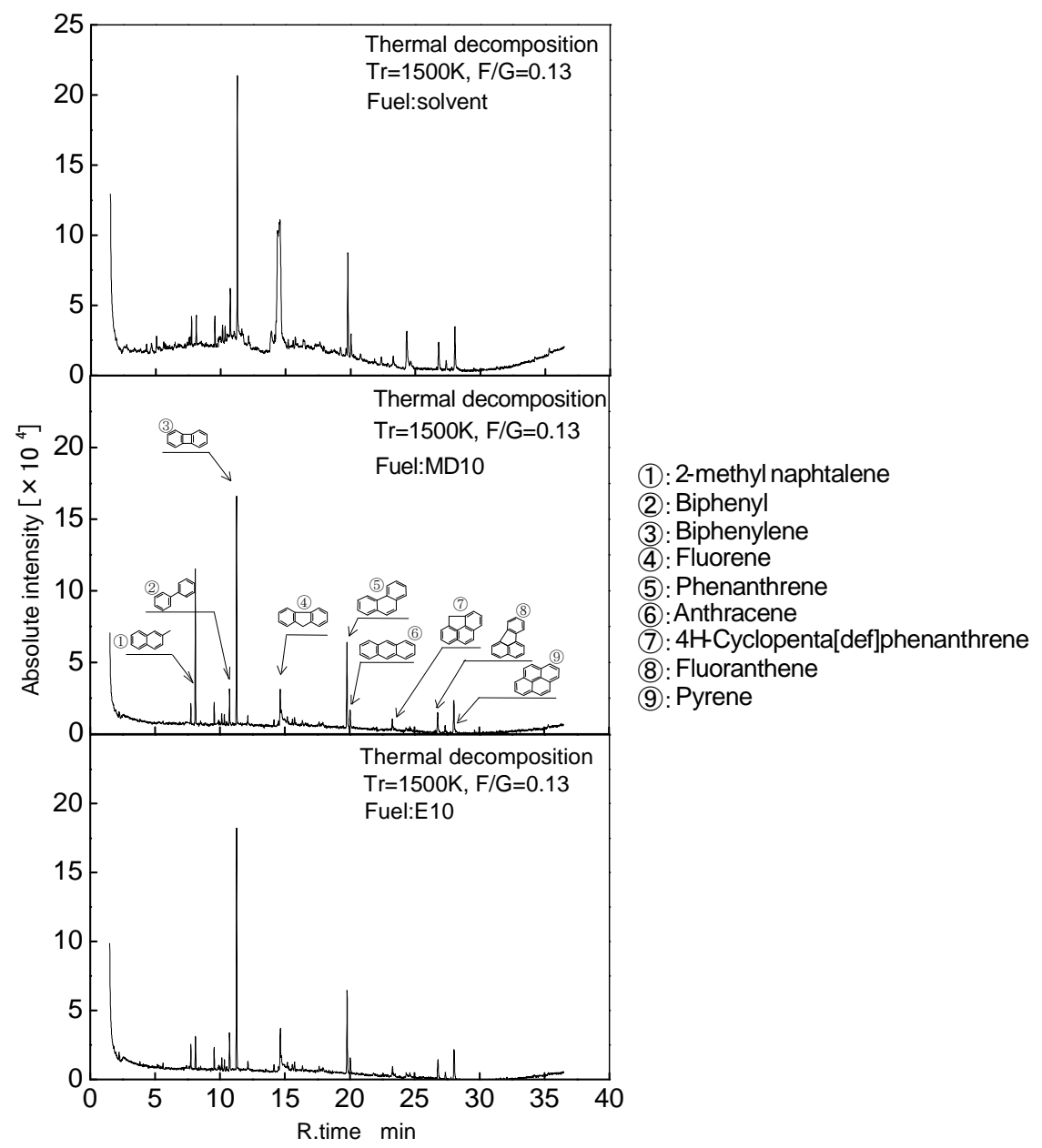

Fig.6 PAHs production during thermal decomposition of Solvent, E10 and MD10 in the flow reactor on the condition of $\operatorname{Tr}=1500 \mathrm{~K}, \mathrm{~F} / \mathrm{G}=0.13$

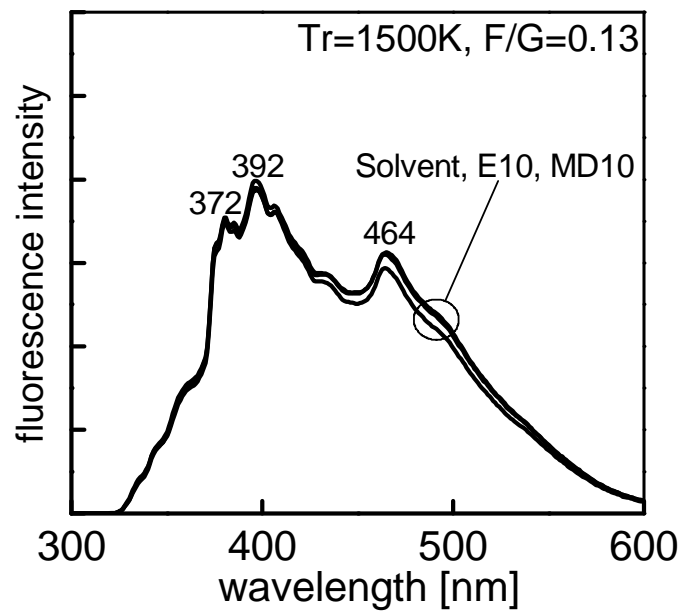

Fig.7 Fluorescence spectra of PAHs over 4 aromatic rings produced by thermal decomposition at $1500 \mathrm{~K}, \mathrm{~F} / \mathrm{G}=0.13$ 


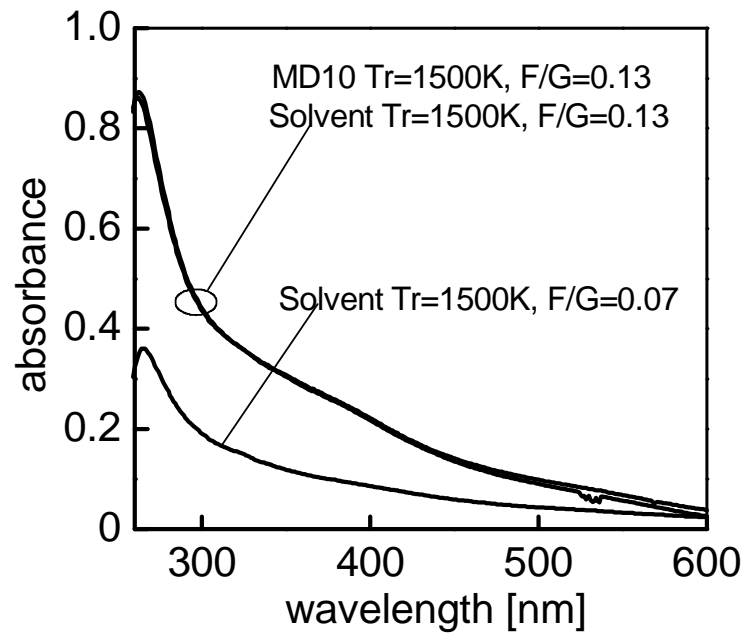

Fig.8 UV-VIS absorption spectra of small particulate produced by thermal decomposition

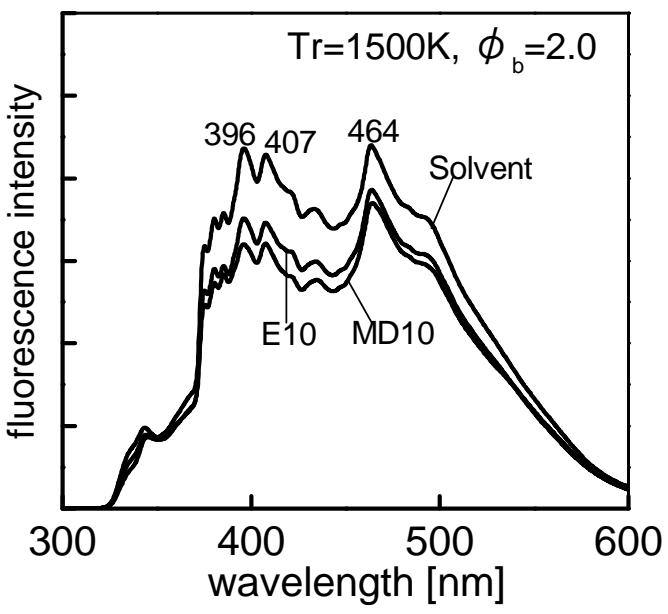

Fig.9 Fluorescence spectra of PAHs over 4 aromatic rings in SOF extracted from exhaust PM at $1500 \mathrm{~K}, \varphi_{\mathrm{b}}=2.0$

\section{4. まと め}

ディーゼル燃燒においてBDF混合燃料の熱分解とPM低減の関係を化学的に調べるため, 直鎖飽和炭化水素燃料

(Solvent) と，これにデカン酸メチルを10vol.\%混合させた燃料（MD10)，およびエタノールを10vol.\%混合させ た燃料（E10）を供試燃料として流通反応装置により熱分解させ，生成した熱分解成分を層流拡散バーナで然焼 させる燃焼実験を行った. 熱分解成分の分析, 排気ガス中のPM生成量の測定, PAHsの定性分析より, BDF燃料 の熱分解によるLHC，PAHs生成と排気PM生成について，以下のことが明らかとなった.

(1) E10，MD10は，燃料過濃な拡散燃焼でSolventに比べて20３0\%のPMを低減させ，とくにSolidの低減に効果 的である.

(2) 燃料の酸素含有率が増加すると, 熱分解で生成するLHCが低減するとともにPMも低減する傾向を示す.

(3) $\mathrm{MD} 10$ は, 熱分解において $\mathrm{CO}_{2}$ が多く生成してす寸前駆物質生成に関係すると考えられる $\mathrm{C}_{2} \mathrm{H}_{2}$ の生成量が大き く低減し，PM低減効果が高まる.

(4) MD10，E10では，熱分解で3環以上のPAHsの生成が抑制される.

(5) 本実験手法においては，熱分解における4環以上のPAHs と直径20nm以下の寸寸粒子生成に差異は見出せない が，熱分解で準備されるLHCやPAHsが減少すると，燃焼により生成するす寸前駆物質ならびにPM生成濃度 が低減すると考えられる. 
謝 辞

おわりに, 伊山博輝君（現：立命館大学）には本実験にご協力頂き, 分析装置の利用に関しては, 京都府中小企 業技術センター中丹技術支援室のご協力を得た。ここに記して感謝の意を表します.

\section{文献}

(1) Olivier, H., William, J. P. and Charls, K. W., "Detailed chemical kinetic oxidation mechanism for a biodiesel surrogate", Combustion and Flame, Vol. 154 (2008), pp.507-528.

(2) James, P. S., Andre, L. B., Daniel, C. H. and Hibiki, K., "Premixed ignition behavior of alternative diesel fuel-relevant compounds in a motored engine experiment", Combustion and Flame, Vol.149 (2007), pp.112-128.

（3）河崎澄，原建，松田敏裕，山根浩二, “バイオディーゼル燃料機関の燃焼および排気に及ぼす EGR の影響”, 日本機 械学会論文集 B 編, Vol.73, No.736 (2007), pp.2587-2592.

（4）木下英二, 植田裕, 高田聖士, “パーム油イソブチルエステルのディーゼル燃焼特性”,自動車技術会論文集, Vol.40, No.5 (2009), pp.1357-1362.

(5) Wira, J., Toru, H., Syunsuke, K., Yoshiyuki, K. and Kei, M., "Improvement of Emission in a DI Diesel Engine Fuelled by Bio-diesel Fuel and Waste Cooking Oil", Transactions of the Society of Automotive Engineers, No.2007-01-2029 (2007), pp.1-10.

(6) Henry, J.C, William, J. P., Nick, M. M., Charls, K. W., Philippe, D., Jean, C. B. and Michel, C., “A Wide Range Modeling Study of Dimethyl Ether Oxidation", Lawrence Livemore National Laboratory Report, UCRL-JC-127071, (1997).

(7) Nick, M. M., “A Detailed Chemical Kinetic Modeling for High Temperature Ethanol Oxidation”, International. Journal of Chemical Kinetics, Vol.31(1999), pp.183-220.

(8) 北村高明，千田二郎，藤本元，”含酸素燃料の寸寸生成抑制効果に関する化学反応論的解析- 第一報:含酸素燃料構 造が PAH 生成特性に及ぼす影響”-,自動車技術会論文集, Vol.32, No.1 (2001), pp.41-46.

（9）小川 英之, 屋木 理志, 宮本 登, “含酸素燃料の PAH 生成機構に関する化学動力学的解析”, 自動車技術会論文 集，Vol.33, No.4 (2002), pp.85-90.

(10) 野毛宏文, 長谷川諭, 吉原雄一, 木戸口善行, 三輪惠, ”側鎖構造をもつディーゼル燃料の拡散燃焼バーナによる す寸生成に関する研究”，日本機械学会論文集 B 編，Vol.38, No.5 (2007), pp.95-100.

(11) Bartok, W., and Sarofim, A. F., Fossile Fuel Combustion (1991), p.144, John Wiley \& Sons, Inc.

(12) Tregrossi, A., Barbella, R. and Ciajilo, A., "Spectral Properties of Soot in the UV-Visible Range", Combustion Science and Technology, Vol.179 (2007), pp.371-385.

(13) Alfe M., Apicella, B., Barbella, R., Tregrossi, A. and Ciajolo, A., "Temperature effect on soot size distribution of sooting premixed flames", Proceedings of the $4^{\text {th }}$ European Combustion Meeting, (2009), pp.1-4. 